\title{
How to Choose Your Next Top Salesperson: Multiple-Criteria Approach
}

\section{Violeta Cretkoska}

Ss. Cyril and Methodius University in Skopje, Faculty of Economics - Skopje, Republic of Macedonia

Filip Iliev

WVP Group, Republic of Macedonia

\section{Abstract}

Background: Choosing the most suitable candidate for the position of salesperson is indeed a complex task for managers because several criteria important for the position should be taken into consideration. Such a choice should be considered as a multiple-criteria problem, which can be solved by using the AHP method. Objectives: The main goal is to investigate which criteria are the most important for the managers in the process of selecting a candidate for the position of salesperson, and on that basis to develop an AHP model for ranking of applicant candidates for this position. Methods/Approach: A questionnaire was created, which was sent to 100 sales managers in companies of different industries in Macedonia, in order to grade the importance of the given criteria. Out of the criteria graded, nine that have the highest average grade of importance comprise one of the levels of the AHP model. Results: An average grade of importance for the criteria for choosing a candidate for the position of salesperson is gained, and an AHP model is developed. Conclusions: The developed AHP model is illustrated through a hypothetical example, and its solution serves as a recommendation for who is the best candidate.

Key words: sale, sales managers, salesperson, multiple-criteria approach, AHP JEL classification: C44, C83, M21

Paper type: Research article

Received: Nov 09, 2016

Accepted: Feb 04, 2017

Citation: Cvetkoska, V., lliev, F. (2017), "How to Choose Your Next Top Salesperson: Multiple-Criteria Approach", Business Systems Research, Vol. 8, No. 1, pp. 92-112.

DOI: 10.1515/bsrj-2017-0008

\section{Introduction}

Everything starts from sales; nothing happens until a sale happens. Moreover, the sale itself does not merely represent a final transaction for selling products or services, but it also stands for negotiation, finding the best employees, transmitting the idea for the business, keeping up a good atmosphere in the company, building strategic alliances, opening new businesses, establishing good relations with the suppliers and the rest of the stakeholders, etc., i.e. a sale is every communication of any type that we utilize to achieve our goals. Consequently, it requires daily investing in oneself (in one's complete personal development) and as such represents one of the most 
complex profiles, especially because of the fact that human nature is immeasurable and there is no formula for successful communication in different situations.

Out of the people that are included in sales, $55 \%$ have chosen the wrong profession, while another $20-25 \%$ have the essential attributes so as to be able to sell, yet they don't need to sell that which they are given but rather something else (Greenberg et al., 2001, p. 9).

According to Mayer et al. (1964), two basic principles are essential for a good salesperson, and they are: empathy and ego-drive. In addition, according to Kurlan (2009, pp. 2-3) the following four elements are crucial to sales success: desire, commitment, outlook and, responsibility. Successful salespeople possess five key qualities: empathy, focus, responsibility, optimism, and ego-drive. Choi et al. (2015) investigate the influence of the characteristics of the salesperson on the behaviour of a buyer in the buyer-supplier relationship. Sales professionals (a number of 155) of manufacturers in Japan have provided the data, and in order to analyse it the structural equation modelling approach was used. Loveland et al. (2015) examine the relationship between personality traits and job satisfaction and career satisfaction in the case of salespeople. The sample comprised 299 salespeople and the latent profile analysis (LPA) was used to assess this sample along with the following personality dimensions: emotional stability, extraversion, work drive, teamwork orientation, customer service orientation, optimism, job satisfaction and career satisfaction. Job satisfaction and career satisfaction were used as dependent variables. Yakasai et al. (2015) investigate the impact of the Big Five Factors of personality traits on the performance of salespeople. Moreover, the five personality dimensions are: extraversion, agreeableness, conscientiousness, neuroticism, and openness.

For the purpose of determining which criteria are most important for sales managers when choosing a candidate for the position of salesperson in companies that belong to different industries in Macedonia, a research was conducted through a questionnaire, and the chosen criteria are the basis for the development of the multiple-criteria AHP (Analytic Hierarchy Process) model.

A literature review for multiple-criteria decision making (MCDM) techniques and their application has been made by Mardani et al. (2015). The authors considered 393 articles, published in more than 120 international peer-reviewed journals from the Web of Science database in the period 2000-2014 (Cvetkoska et al., 2016). According to the frequency of application of decision-making techniques (AHP, ELECTRE, DEMATEL, PROMETHEE, TOPSIS, ANP, aggregation DM methods, hybrid MCDM and VIKOR), the one used the most is the AHP (128 articles), followed by: the hybrid MCDM (64 articles), aggregation DM methods (46 articles), TOPSIS (45 articles), ELECTRE (34 articles), ANP (29 articles), PROMETHEE (26 articles), VIKOR (14 articles), and DEMATEL (7 articles) (Cvetkoska et al., 2016, p. 242). The analytic hierarchy process is the best known and most frequently used multiple-criteria method that allows for the choice of the best alternative from those available, which are evaluated on the basis of several criteria, i.e. sub-criteria. The decision-making problem is structured as a hierarchy, for details see (Saaty et al., 1994, p. 2), and on the same level there should be $7 \pm 2$ elements, for more details, see (Miller, 1956). Following the development of the hierarchy model, its constituent elements are compared in pairs. According to cognitive psychologists, people make two types of comparisons: absolute and relative comparisons. With the former, the alternatives are compared to a standard, while with the latter, the alternatives according to which the attribute is mutual are compared in pairs, and the AHP method can be 
used both for absolute and relative comparisons (Saaty et al., 1994, Saaty, 2005). In this paper, the AHP method is used for absolute comparisons.

In Macedonia, Cvetkoska et al. (2014) have developed an AHP model for ranking the candidates for the position of project manager. In the existing literature we were not able to find a paper containing a research like ours, regarding the choice of best candidate for the position of salesperson by implementing the multiple-criteria approach, which leads to the conclusion that this is an original research.

The paper is structured as follows: apart from the Introduction that is given in Section 1, Section 2 refers to the methodology. The results are presented in Section 3, whereas the discussion is presented in Section 4. At the end, the Conclusion is given in Section 5.

\section{Methodology}

In the focus of this paper is the selection of relevant criteria and defining a relevant multiple-criteria model for choosing the best salesperson.

A questionnaire, which consisted of a total of 36 questions, was prepared; the target group being the sales managers employed in companies in different industries in Macedonia. The questionnaire is given in Appendix 1.

Aside from the questions regarding gender, age, level of education, and where the sales managers had acquired their highest level of education, we wanted to gain information as well about the industry of the company they work at, the number of employees in the company, and the number of employees in the sales sector. Additionally, we wanted to observe how many years the new salespeople needed to reach the point of being sales experts who could train future salespeople.

Additionally, answers were obtained about the best way of doing sales, the best way of paying managers and salespeople, as well as the benefits for sales managers and salespeople. Moreover, we wanted every sales manager to identify the three largest advantages and disadvantages that building one's career in sales has.

This paper places emphasis on the last question of the questionnaire, with the aim of choosing the most important criteria for the choice of candidate for the position of salesperson. The last question contained 22 criteria (formal education, attended trainings in the required field of expertise, attended trainings aside from the required field of expertise, previous working experience related to sales, candidate's motivation, knowledge of English, knowledge of a foreign language other than English, organizational skills, communication skills, negotiation skills, computer skills, time management, leadership, teamwork, integrity, problem management, vision for oneself, change management, self-discipline, looks, coming from an entrepreneurial family, and coming from a family that was involved in sales) that the sales managers had to grade according to the importance they placed in regards to the choice of candidates for the position of salesperson. In order to grade the importance of every criterion, a scale from 1 to 5 was given, where 1 stands for the least important, while 5 stands for the most important. In addition, the sales managers were given the chance to add and grade the criteria that according to them is also important, but has not been mentioned. The questionnaire was sent to 100 sales managers by email in March 2016, and they were given a period of one week to fill it in and send it back to the authors of this paper.

The Analytic Hierarchy Process is the most commonly used MCDM method when a choice of best alternative from several alternatives has to be made, or when alternatives should be ranked so that multiple criteria are taken into consideration on the basis of which alternatives are graded. In our paper a multiple-criteria AHP 
model will be developed, consisting of a goal (the choice of best candidate for the position of salesperson), criteria (on the basis of the answers received, nine that have the highest average grade of importance will be chosen), and intensities, while the solution will serve as a recommendation of the best candidate for the position of salesperson. The Analytic Hierarchy Process is further explained.

\section{The Analytic Hierarchy Process (AHP)}

Thomas L. Saaty in the late seventies of the previous century developed the multiplecriteria decision-making method Analytic Hierarchy Process (Saaty, 1977, 1980). This method is designed to solve MCDM problems, which can be decomposed into the following elements: goal, criteria, sub-criteria and alternatives, and these elements comprise a hierarchy structure. The elements of each level of the constructed hierarchy are compared in pairs by a decision-maker and they express their preferences by using the scale of relative importance (Table 1). The weights of the criteria and the priorities of the alternatives are the outputs of this method, and in order to calculate them an appropriate mathematical model is used, see more in (Saaty, 1990; Saaty et al., 1991).

\section{Table 1}

Intensity of Importance Scale

\begin{tabular}{|c|c|c|}
\hline $\begin{array}{l}\text { Intensity of } \\
\text { importance }\end{array}$ & Definition & Explanation \\
\hline 1 & Equal importance & $\begin{array}{l}\text { Two activities contribute equally } \\
\text { to the objective }\end{array}$ \\
\hline 2 & Weak & \\
\hline 3 & Moderate importance & $\begin{array}{l}\text { Experience and judgment slightly } \\
\text { favour one activity over another }\end{array}$ \\
\hline 4 & Moderate plus & \\
\hline 5 & Strong importance & $\begin{array}{l}\text { Experience and judgment } \\
\text { strongly favour one activity over } \\
\text { another }\end{array}$ \\
\hline 6 & Strong plus & \\
\hline 7 & $\begin{array}{l}\text { Very strong or demonstrated } \\
\text { importance }\end{array}$ & $\begin{array}{l}\text { An activity is favoured very } \\
\text { strongly over another; its } \\
\text { dominance demonstrated in } \\
\text { practice }\end{array}$ \\
\hline 8 & Very, very strong & \\
\hline 9 & Extreme importance & $\begin{array}{l}\text { The evidence favouring one } \\
\text { activity over another is of the } \\
\text { highest possible order of } \\
\text { affirmation }\end{array}$ \\
\hline $\begin{array}{l}\text { Reciprocals } \\
\text { of above }\end{array}$ & $\begin{array}{l}\text { If activity } i \text { has one of the above non- } \\
\text { zero numbers assigned to it when } \\
\text { compared with activity } j \text {, then } j \text { has } \\
\text { the reciprocal value when compared } \\
\text { with } i\end{array}$ & A reasonable assumption \\
\hline Rationals & Ratios arising from the scale & $\begin{array}{l}\text { If consistency were to be forced } \\
\text { by obtaining n numerical values } \\
\text { to span the matrix }\end{array}$ \\
\hline
\end{tabular}

Source: Saaty et al., 2012. 
In this paper the focus is on the absolute measurement. "After setting priorities for the criteria (or subcriteria, if there are any), pairwise comparisons are also made between the ratings themselves to set priorities for them under each criterion and dividing each of their priorities by the largest rated intensity to get the ideal intensity. Finally, alternatives are scored by checking off their respective ratings under each criterion and summing these ratings for all the criteria. This produces a ratio scale score for the alternative. The scores thus obtained of the alternatives can in the end be normalized by dividing each one by their sum" (Saaty et al., 1994, p. 5). More details about absolute measurement can be found in (Saaty et al., 1994, pp. 17-19; Saaty, 2005, pp. 20-23).

By calculating the Consistency Ratio (C.R.) it can be investigated whether the decision-maker was consistent or not in the process of comparing in pairs the elements of the hierarchy.

C.R.=C.I./R.I., where the Consistency Index $(\mathrm{C} . \mathrm{I})=\left(\lambda_{\max }-n\right) /(n-1), \lambda_{\max }$ represents the largest eigenvalue of the matrix of pairwise comparisons (A), (Saaty and Vargas, 1994, pp. 8-9). In Table 2 the values of the Random Index (R.I.) are given. If it is obtained that the Consistency Ratio is about $10 \%(0.10)$ or less, the decisionmaker is considered to be consistent; if that is not the case then the consistency should be improved (Saaty, 1990, p. 13).

Table 2

Average Random Consistency Index

\begin{tabular}{lllllllllll}
\hline $\mathrm{n}$ & 1 & 2 & 3 & 4 & 5 & 6 & 7 & 8 & 9 & 10 \\
\hline $\begin{array}{l}\text { Random } \\
\begin{array}{l}\text { Consistency Index } \\
\text { (R.I.) }\end{array}\end{array}$ & 0 & 0 & .52 & .89 & 1.11 & 1.25 & 1.35 & 1.40 & 1.45 & 1.49 \\
\hline
\end{tabular}

Source: Saaty et al., 1994.

Some of the advantages of using this multiple-criteria method are (Cvetkoska, 2013 , p. 55) that in the decision-making process it integrates both the quantitative factors and the factors of a qualitative nature, it identifies the inconsistency of the decision-maker, in group decision-making it helps to structure the discussion and thus achieve a consensus, quality software tools have been developed for its support, it enables a sensitive analysis which examines the sensitivity, i.e. the stability of the results obtained, etc. However, aside from the advantages, there are also disadvantages of the AHP method (Cvetkoska, 2013, p. 55): for certain problems in the decision-making process, the intensity of importance scale is not comprehensive enough for comparing the elements in pairs, for a large part of the problems, a high number of comparisons in pairs is needed, it is well-known that it is difficult to achieve an acceptable C.R., and incomparable alternatives can not be taken into consideration. Regarding how the last disadvantage can be overcome, see (Saaty, 2006, p. 225).

In the application of the method of Analytic Hierarchy Process, an integral part is sensitive analysis through which it can be seen:

1. How the change of the input data (criteria/sub-criteria if included) influences the final results, i.e. the overall priorities of the alternatives, and

2. Whether the change of the input data means that the ranking of the alternatives will remain the same or that it will change. 
According to Bayazit (2005) if the input data in every possible combination change for $5 \%$, while the ranking of the alternatives remains the same, then it is thought that the results obtained are stable.

Out of the software tools that serve as support for the AHP method, Expert Choice, has five options for sensitivity analysis: 1. Performance; 2. Dynamic; 3. Gradient; 4. Head to Head and 5. 2 D, details can be found in Babic (2011, pp. 182-185).

\section{Results}

The questionnaire was fully filled in by 52 sales managers, and what follows are the analysed results from the given questions.

Out of 52 respondents, 27 are male, and 25 are female. According to age, the youngest respondent is 25 years old, and the oldest is 57 years. Regarding their level of education, the largest number of the respondents have acquired higher education (35), 10 of them have MA degrees, 6 have vocational education, and 1 is a PhD. Out of the respondents, 47 have gained the highest level of education in Macedonia, while 5 have gained it abroad.

According to the National Classification of Activities - NCA Rev. 2 (Republic of Macedonia State Statistical Office, 2013) (Financial and insurance activities; wholesale and retail trade, repair of motor vehicles and motorcycles; manufacturing; professional, scientific and technical activities; transportation and storage; arts, entertainment and recreation; human health and social work activities; construction; real estate activities; electricity, gas, steam and air conditioning supply), 12 respondents are sales managers in institutions that function in the following industries: financial and insurance activities, wholesale and retail trade, repair of motor vehicles and motorcycles; 10 of them are sales managers in institutions in the framework of the manufacturing industry; etc., and there is 1 respondent each as a sales manager in the industries of construction, real estate activities, and electricity, gas, steam and air conditioning supply (Figure 1).

According to the number of employees in the companies, it is confirmed that 13 of them are micro, 15 are small, and an equal number of companies are mediumsized and large (12 of them). The average number of employees in the sector of sales in micro, small, medium-sized and large companies is 5, 18, 91 and 301, respectively. According to 24 sales managers, the new salespeople will need up to three years to become sales experts who could train the future salespeople, 18 sales managers think that they will need between three and five years, while 10 sales managers think that five to ten years are necessary. According to 46 respondents the best way of doing sales is in person. Out of the respondents, 47 think that advancement in their career is due to their success in sales. According to 44 respondents, the best way for the sales managers to get paid is by means of commission. Aside from that, on the basis of the answers received, it was concluded that motivating salespeople is not done by way of punishment (no respondent chose this answer). According to 29 respondents, the sales manager has equal benefits with the managers of the other sectors, while according to 23 respondents the sales manager has more benefits. Out of the respondents, 31 answered that if salespeople achieve what is required from them or if they overachieve, then they can be given additional benefits. According to 37 respondents the company that they work for invests in their employees in the sales sector by enabling them to participate in trainings. 
Figure 1

Sales managers in certain industries

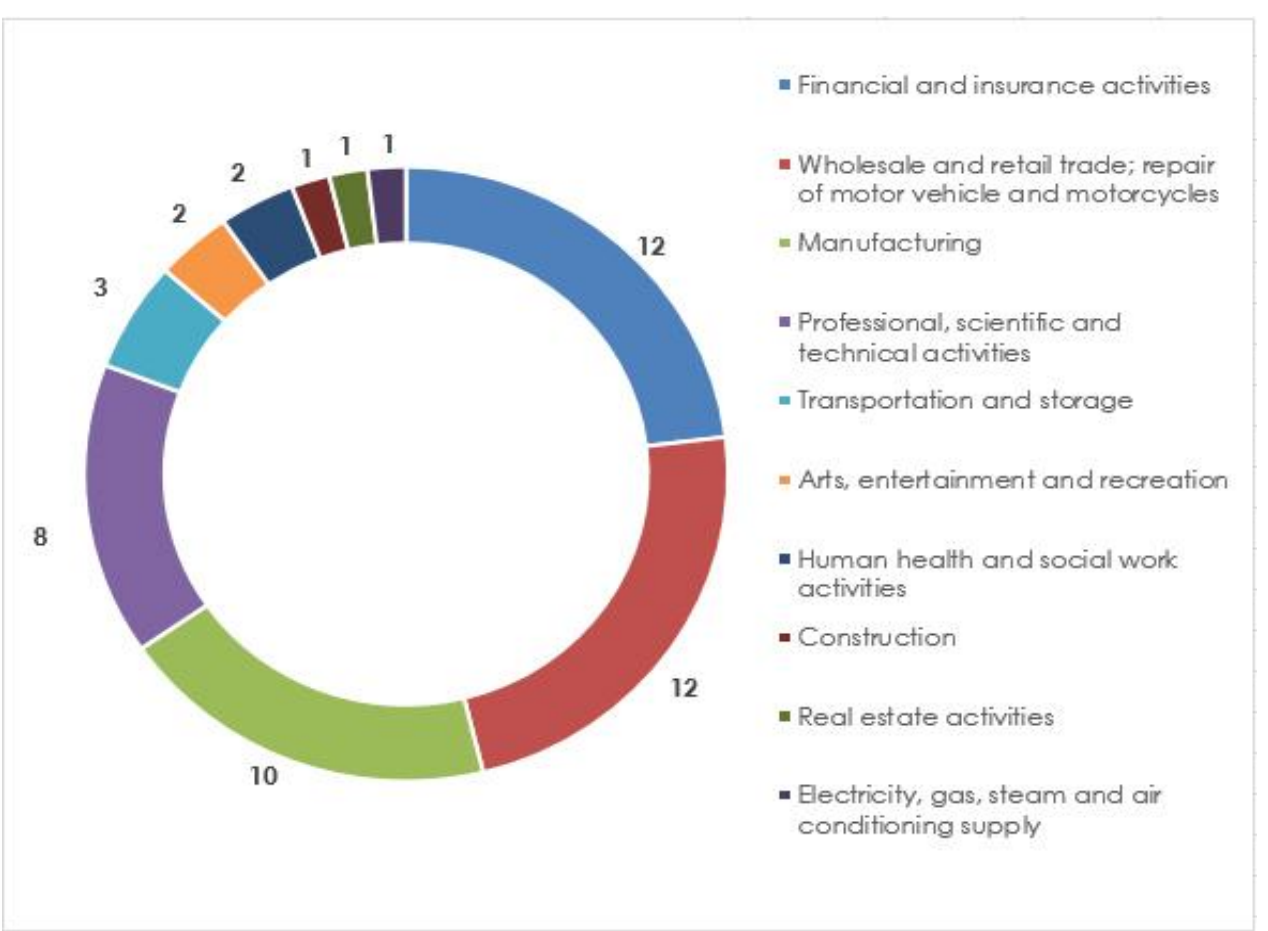

Source: Author's illustration

When selecting candidates for the position of salesperson, the sales managers pay the most attention to the criterion of communication skills (the average grade of importance is 4.86), followed by the criteria of negotiation skills (4.82), self-discipline (4.74), and motivation of the candidate (4.58), while the least important are the following criteria: coming from a family that was involved in sales (2.02), and coming from an entrepreneurial family (1.82) (Table 3). Aside from the stated 22 criteria that the sales managers graded on the given scale, additional criteria were not added.

In order to choose the best candidate for the position of salesperson, we have developed a multiple-criteria AHP model. The goal is to choose the best candidate for the position of salesperson, while the alternatives are the candidates who will apply for this position, and there have been 9 criteria chosen that have the highest average grade of importance from Table 3, those being: communication skills (criterion 1), negotiation skills (criterion 2), self-discipline (criterion 3), motivation of candidate (criterion 4), problem management (criterion 5), teamwork (criterion 6), integrity (criterion 7), change management (criterion 8), and time management (criterion 9). For each of the criteria there have been introduced intensities, so for the criteria of communication and negotiation skills, the intensities are: excellent, average, below-average, weak, unsatisfactory; for the criterion of self-discipline the intensities are: high and low degree of self-discipline; for the criterion of candidate motivation the intensities are: high and low level of motivation; for the criteria of problem management, change management, and time management, the intensities are: excellent, very good, good, weak, and unsatisfactory; for the criterion of integrity the intensities are a high or a low level of integrity; for the criterion of teamwork, if the candidate is a team player, they shall be given the priority value of this criterion, whereas if they aren't a team player, then they shall get 0 . The constructed model is shown in Figure 2. 
Table 3

Average grade of importance for criteria for the choice of candidate for the position of salesperson

\begin{tabular}{lc}
\hline Criteria & Mean \\
\hline Communication skills & 4.86 \\
Negotiation skills & 4.82 \\
Self-discipline & 4.74 \\
Motivation of candidate & 4.58 \\
\hline Problem management & 4.48 \\
\hline Teamwork & 4.44 \\
\hline Integrity & 4.38 \\
Change management & 4.36 \\
\hline Time management & 4.34 \\
English proficiency & 4.24 \\
Organizational skills & 4.22 \\
\hline Vision for oneself & 4.20 \\
\hline Leadership & 4.04 \\
\hline Computer skills & 4.00 \\
\hline Attended training in the required field of expertise & 3.74 \\
\hline Previous working experience related to sales & 3.72 \\
\hline Looks & 3.62 \\
\hline Knowledge of a foreign language other than English & 3.58 \\
\hline Formal education & 3.48 \\
\hline Attended training out of the required field of expertise & 2.84 \\
\hline Coming from a family that was involved in sales & 2.02 \\
\hline Coming from an entrepreneurial family & 1.82 \\
\hline Soure:Autho's
\end{tabular}

Source: Author's calculations

Figure 2

AHP model for applicant candidates ranking for the job position of salesperson

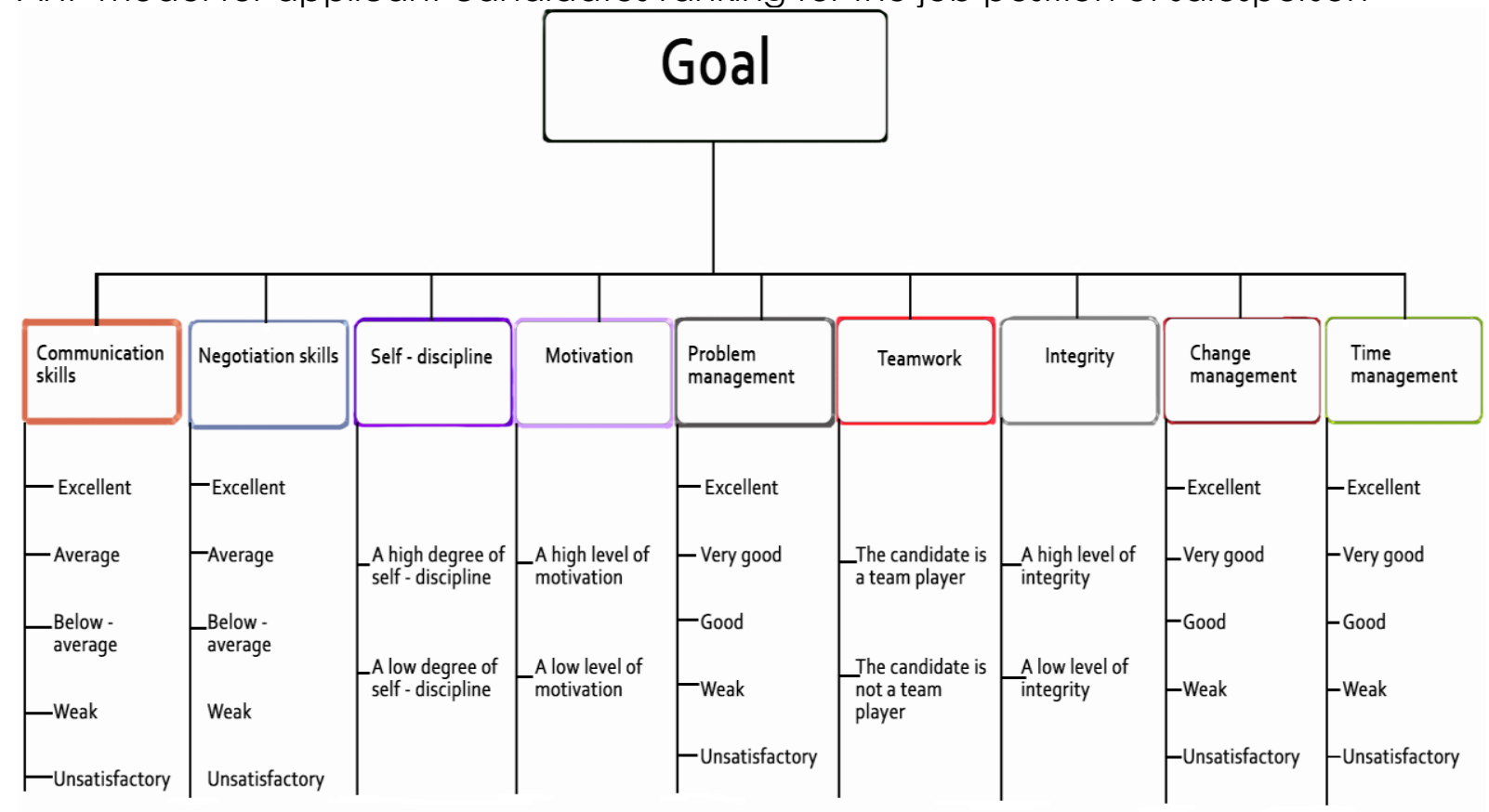

Source: Author's illustration 


\section{A Hypothetical Example for Applicant Candidates' Ranking for the Job Position of a Salesperson}

Table 4 shows the matrix of pairwise comparisons, whereas Table 5 shows the normalized matrix and the priorities. The first criterion, i.e. communication skills, has the highest priority (0.2023), followed by the second and the fourth criterion, i.e. negotiation skills and motivation, etc.

Table 4

Matrix of pairwise comparisons of the criteria

\begin{tabular}{cccccccccc}
\hline & C1 & C2 & C3 & C4 & C5 & C6 & C7 & C8 & C9 \\
\hline C1 & 1 & 2 & 3 & 2 & 4 & 3 & 2 & 3 & 2 \\
C2 & $1 / 2$ & 1 & 3 & 4 & 3 & 4 & 2 & 2 & 2 \\
C3 & $1 / 3$ & $1 / 3$ & 1 & $1 / 2$ & 3 & 2 & $1 / 2$ & 3 & 2 \\
C4 & $1 / 2$ & $1 / 4$ & 2 & 1 & 4 & 3 & 2 & 4 & 4 \\
C5 & $1 / 4$ & $1 / 3$ & $1 / 3$ & $1 / 4$ & 1 & $1 / 3$ & $1 / 3$ & 2 & $1 / 4$ \\
C6 & $1 / 3$ & $1 / 4$ & $1 / 2$ & $1 / 3$ & 3 & 1 & $1 / 3$ & 2 & $1 / 3$ \\
C7 & $1 / 2$ & $1 / 2$ & 2 & $1 / 2$ & 3 & 3 & 1 & 5 & 5 \\
C8 & $1 / 3$ & $1 / 2$ & $1 / 3$ & $1 / 4$ & $1 / 2$ & $1 / 2$ & $1 / 5$ & 1 & $1 / 4$ \\
C9 & $1 / 2$ & $1 / 2$ & $1 / 2$ & $1 / 4$ & 4 & 3 & $1 / 5$ & 4 & 1 \\
\hline
\end{tabular}

Source: Author's calculation

Table 5

Normalized matrix and priorities

\begin{tabular}{|c|c|c|c|c|c|c|c|c|c|c|}
\hline & C1 & $\mathrm{C} 2$ & C3 & C4 & C5 & $\mathrm{C} 6$ & C7 & C8 & C9 & Priorities \\
\hline C1 & 0.2353 & 0.3529 & 0.2368 & 0.2202 & 0.1569 & 0.1513 & 0.2335 & 0.1154 & 0.1188 & 0.2023 \\
\hline C2 & 0.1176 & 0.1765 & 0.2368 & 0.4404 & 0.1176 & 0.2017 & 0.2335 & 0.0769 & 0.1188 & 0.1911 \\
\hline C3 & 0.0784 & 0.0588 & 0.0789 & 0.0550 & 0.1176 & 0.1008 & 0.0584 & 0.1154 & 0.1188 & 0.0869 \\
\hline C4 & 0.1176 & 0.0441 & 0.1579 & 0.1101 & 0.1569 & 0.1513 & 0.2335 & 0.1538 & 0.2376 & 0.1514 \\
\hline C5 & 0.0588 & 0.0588 & 0.0263 & 0.0275 & 0.0392 & 0.0168 & 0.0389 & 0.0769 & 0.0149 & 0.0398 \\
\hline C6 & 0.0784 & 0.0441 & 0.0395 & 0.0367 & 0.1176 & 0.0504 & 0.0389 & 0.0769 & 0.0198 & 0.0558 \\
\hline C7 & 0.1176 & 0.0882 & 0.1579 & 0.0550 & 0.1176 & 0.1513 & 0.1167 & 0.1923 & 0.2970 & 0.1438 \\
\hline C8 & 0.0784 & 0.0882 & 0.0263 & 0.0275 & 0.0196 & 0.0252 & 0.0233 & 0.0385 & 0.0149 & 0.0380 \\
\hline C9 & 0.1176 & 0.0882 & 0.0395 & 0.0275 & 0.1569 & 0.1513 & 0.0233 & 0.1538 & 0.0594 & 0.0908 \\
\hline
\end{tabular}

C.I. $=0.1386$ C.R. $=0.0956$

Source: Author's calculation

Table 6 demonstrates the matrix of pairwise comparisons of the intensities with respect to the first criterion, i.e. communication skills, the priorities and the idealized priorities, whereas the matrixes of pairwise comparisons of the intensities with respect to the other criteria are given in Appendix 2. The author was consistent in the process of comparing the elements of the constructed hierarchy (Consistency Ratio is less than 0.10).

Table 6

Matrix of painwise comparisons of the intensities with respect to the criterion 1, priorities and idealized priorities

\begin{tabular}{|c|c|c|c|c|c|c|c|}
\hline Criterion 1 & Excellent & Average & $\begin{array}{c}\text { Below } \\
\text { average }\end{array}$ & Weak & Unsatisfactory & Priorities & $\begin{array}{l}\text { Idealized } \\
\text { Priorities }\end{array}$ \\
\hline Excellent & 1 & 3 & 5 & 7 & 9 & 0.5028 & 1.0000 \\
\hline Average & $1 / 3$ & 1 & 3 & 5 & 7 & 0.2602 & 0.5175 \\
\hline $\begin{array}{l}\text { Below } \\
\text { average }\end{array}$ & $1 / 5$ & $1 / 3$ & 1 & 3 & 5 & 0.1344 & 0.2672 \\
\hline Weak & $1 / 7$ & $1 / 5$ & $1 / 3$ & 1 & 3 & 0.0678 & 0.1348 \\
\hline Unsatisfactory & $1 / 9$ & $1 / 7$ & $1 / 5$ & $1 / 3$ & 1 & 0.0348 & 0.0693 \\
\hline
\end{tabular}

C.I. $=0.0607$ C.R. $=0.0546$

Source: Author's calculation 
Table 7 presents a short version of how the applicant candidates' ranking for the job position of salesperson shall be made.

Three alternatives i.e. three candidates $(A, B, C)$, are taken into consideration and what follows is an illustration how the total score for Candidate $A$ is calculated:

$0.2023 \times 0.5175+0.1911 \times 0.2672+0.0869 \times 1.0000+0.1514 \times 1.0000+0.0398 \times$ $0.3445+0.0558+0.1438 \times 1.0000+0.0380 \times 0.3445+0.0908 \times 0.3445=0.3169$

The total score for the rest of the candidates is calculated in an analogical way. Then, the normalized priorities are calculated, and the last row in Table 7 (Ranking) shows that ranked first is Candidate $B$, followed by the Candidates $A$, and $C$.

Table 7

Ranking Candidates

\begin{tabular}{|c|c|c|c|c|}
\hline & & A & B & C \\
\hline C1 & 0.2023 & Average & Excellent & Average \\
\hline $\mathrm{C} 2$ & 0.1911 & $\begin{array}{c}\text { Below } \\
\text { average }\end{array}$ & Average & $\begin{array}{l}\text { Below } \\
\text { average }\end{array}$ \\
\hline C3 & 0.0869 & $\begin{array}{l}\text { A high } \\
\text { degree }\end{array}$ & $\begin{array}{l}\text { A high } \\
\text { degree }\end{array}$ & $\begin{array}{c}\text { A low } \\
\text { degree }\end{array}$ \\
\hline C4 & 0.1514 & $\begin{array}{l}\text { A high } \\
\text { level }\end{array}$ & $\begin{array}{l}\text { A high } \\
\text { level }\end{array}$ & $\begin{array}{l}\text { A high } \\
\text { level }\end{array}$ \\
\hline C5 & 0.0398 & Good & Excellent & Weak \\
\hline $\mathrm{Cb}$ & 0.0558 & $\begin{array}{l}\text { Is not a } \\
\text { team } \\
\text { player }\end{array}$ & $\begin{array}{l}\text { Is a } \\
\text { team } \\
\text { player }\end{array}$ & $\begin{array}{l}\text { Is a } \\
\text { team } \\
\text { player }\end{array}$ \\
\hline C7 & 0.1438 & $\begin{array}{l}\text { A high } \\
\text { level }\end{array}$ & $\begin{array}{l}\text { A high } \\
\text { level }\end{array}$ & $\begin{array}{l}\text { A low } \\
\text { level }\end{array}$ \\
\hline C8 & 0.0380 & Good & $\begin{array}{l}\text { Very } \\
\text { good }\end{array}$ & Weak \\
\hline C9 & 0.0908 & Good & $\begin{array}{l}\text { Very } \\
\text { good }\end{array}$ & Weak \\
\hline Total score & & 0.5960 & 0.8550 & 0.4299 \\
\hline Priorities & (normalized) & 0.3169 & 0.4546 & 0.2286 \\
\hline Ranking & & 2 & 1 & 3 \\
\hline
\end{tabular}

Source: Author's calculation

\section{Discussion}

With the development of technology a great number of professions that exist nowadays will become extinct in the near or distant future. Moreover, a significant number of people who have dedicated their whole life to acquiring certain skills will have to develop new ones or face a dramatic fall of the cost of their hard work. The respondents were asked the question as to what, in their opinion, is the best way to do sales (face-to-face, group presentations, via the internet, via a phone call, or they could add another option) $-88.46 \%$ of them (46 respondents) answered that the best way to do sales is face-to-face, while $86.5 \%$ of them (45 respondents) already do sales in this way. Can this lead us to the conclusion that this area is immune to the development of technology and that it can't become extinct even after thousands of years of continuous development of technology, because nothing can replace human contact? The wholesome impression that we leave on 
other people depends on what we say, the way we say it, and our body language. According to Albert Mehrabian only $7 \%$ depends on "what" we say, 38\% depends on the way we say it, and as much as $55 \%$ depends on our body language (Belludi, 2008). Consequently, does this imply that when a sale is being done via the internet the chances to leave the correct impression are around $7 \%$, while via a phone call they are $45 \%$, and the chances to send the message in the correct way are around $55 \%$ higher, i.e. around $93 \%$, if it is done in person?

From the very first moment human beings stood upright up to today on a daily basis they have had one goal: to move forward in their development. Those who want to work in sales should bear in mind that their career development will depend on their success in sales, $90.38 \%$ of the respondents answered that their personal advancement in sales is due to their success in sales, and $86.54 \%$ of the respondents answered that advancement of salespeople in their whole career is due to their success in sales.

According to $84.62 \%$ of the respondents (44 in number) the best way for the managers to get paid is by commission, while $55.77 \%$ of them (29 respondents) answered that in the company they work for, the sales managers are paid by managerial and sales commission, as a percentage of the sales. According to $88.46 \%$ of the respondents (46 in number) the best way to pay the salespeople is by commission, and according to $55.77 \%$ (29 respondents) the salespeople are paid by commission as a percentage of their sales. Such a way of getting paid creates additional pressure on the salespeople and sales managers, from the aspect of fulfilling the assigned tasks (in the financial sector, on a quarterly level). However, if it is taken into consideration that every line of work brings along certain pressure with it, as opposed to the largest part of professions where bad results most often lead to getting fired, in sales, motivating the salespeople by punishing them is $0.00 \%$, which in fact is an advantage because bad results can only lead to decreasing financial benefit, but they get to keep their job and gain a lot of time to better their performance, except in the case of continuous bad results (in two or more quarters).

The sales managers, in regards to the managers from the other sectors, have equal benefits (55.77\% or 29 respondents), i.e. more benefits (44.23\% or 23 respondents), expressed in higher salaries and additional benefits. According to $59.62 \%$ of the respondents (a number of 31 ), the salespeople have additional benefits, such as: physical rewards, trainings and trips abroad, while according to $40.38 \%$ (a number of 21), they don't have additional benefits. According to $71.15 \%$ of the respondents (a number of 37), the company they work for provides trainings for skills advancement in sales, which are held by experienced company employees or trainers who come to the company, or they send their employees to participate in such trainings in Macedonia and abroad. On the basis of the answers received, it can be concluded that the companies invest in their employees, which at the same time presents an investment with the greatest return.

When making decisions from a tactic or/and strategic aspect, those in the company responsible for making decisions often consult the best salespeople $142.3 \%$ or 22 respondents), and according to $26.92 \%$ ( 14 respondents) they do it nearly every time.

When selecting candidates for the position of salesperson, the sales managers pay the most attention to: communication skills, negotiation skills, self-discipline, and motivation of the candidate (with average grades of importance of over 4.5), followed by problem management, teamwork, integrity, change management, time management, knowledge of English (which is necessary in a globalized world), 
organizational skills, vision for themselves, leadership and computer skills (with the average grades of importance of over 4.00). The criteria with average grades of importance less than 4.00 are: attended trainings in the required field of expertise, previous working experience related to sales, looks, knowledge of a foreign language other than English, formal education, and attended trainings out of the required field of expertise.

As an encouragement to the fact that the candidates are more and more dependent on their own skills in this profession, these two criteria are of the least importance: coming from a family that was involved in sales, and coming from an entrepreneurial family.

The average grade of importance for each criterion, calculated on the basis of the grades given from 1 to 5 by the sales managers, enables the identification of the most significant criteria for the choice of candidate for the position of salesperson. Out of 22 criteria, 9 have been chosen with the highest average grade of importance, which comprise one of the levels of the multiple-criteria AHP model. When the AHP model is applied, the maximum number of elements on the levels is 9, which is why 9 criteria have been chosen.

The developed AHP model is illustrated on a hypothetical example, and it shall enable the sales managers to choose the best candidate for the position of salesperson.

\section{Conclusion}

In this paper it is determined which are the most important criteria for sales managers in the process of selecting a candidate for the position of salesperson, and on that basis an AHP model for ranking of applicant candidates for this position is developed. A questionnaire and absolute measurement approach of the method analytic hierarchy process were used in that direction. The most important 9 criteria by the sales managers were: communication skills, negotiation skills, self-discipline, candidate's motivation, problem management, teamwork, integrity, change management, and time management. The goal in the AHP model was to choose the best candidate for the position of salesperson, the criteria being the 9 mentioned ones, while the alternatives are all the candidates who will apply. How the applicant candidates' ranking shall be made for the job position of salesperson is illustrated in a hypothetical example, and the solution of the developed model shall be used as a recommendation in the process of choosing the best candidate for the position of salesperson by the sales managers.

In Macedonia, Cvetkoska et al. (2014) have developed an AHP model for ranking of candidates for the position of Project Manager. The model consists of a goal (candidates' ranking for the position of Project Manager); criteria (the following seven criteria that were chosen the most by the interviewees were selected [30 owners and/or managers of small and medium-sized enterprises]: education, specific work experience, level of English proficiency, PM Software usage skills, organization skills, analytical skills, and PMP Certificate); intensities of the criteria; and alternatives (the candidates who shall apply for this job position). In the existing literature there has not been found a paper with a research like ours, which means that this is an original research.

The largest wealth of a company are its employees because the intellectual capital can not be copied by the competition. Therefore, the selection of employees should not be based solely on intuition and experience, but it is necessary quantitative methods to be used, as well as models that will help managers to make 
good decisions. In the AHP model that was developed in this paper, the knowledge of sales managers who are experts in sales is incorporated, and it will help companies to select the right people for the job position of salesperson.

The limitations of this study regard the small number of fully filled-in questionnaires by the sales managers, although our opinion is that there would have been no significant differences in the obtained results. Our future research will consist of distributing the questionnaire to sales managers in companies in the Balkan countries, and then we will include all European countries in order to develop a model that will be widely applicable.

\section{References}

1. Babic, Z. (2011). Models and methods of business decision-making, Split, University of Split, Faculty of Economics. (on Croatian)

2. Bayazit, O. (2005), "Use of AHP in decision-making for flexible manufacturing systems", Journal of Manufacturing Technology Management, Vol.16 No. 7, pp. 808-819.

3. Belludi, N. (2008), "Albert Mehrabian's 7-38-55 rule of personal communication", available at: http://www.rightattitudes.com/2008/10/04/7-38-55-rule-personalcommunication (20 September 2016)

4. Choi, Y., Huang, Y., Sternquist, B. (2015), "The effects of the salesperson's characteristics on buyer-seller relationships", Journal of Business \& Industrial Marketing, Vol. 30 No. 5, pp. 616-625.

5. Cvetkoska, V. (2013), "Methods and models of multi-criteria decision making in management: An empirical study on evaluation of the efficiency of certain organizational units in the Republic of Macedonia", Ph.D. dissertation, Ss. Cyril and Methodius University in Skopje, Faculty of Economics-Skopje. (on Macedonian)

6. Cvetkoska, V., Begicevic-Redzep, N. (2016), "Applying the analytic hierarchy process to rank city-branches", in Book of Proceedings of the XV International Symposium SYMORG2016, 10-13 June, 2016, Zlatibor, Serbia, University of Belgrade, Faculty of Organizational Sciences, Belgrade, pp. 241-252.

7. Cvetkoska, V., Danilov, M. (2014), "Candidates' ranking for the project manager job position: Absolute measurement", in Book of Proceedings of the International May Conference on Strategic Management - IMKSM2014, 23-25 May, 2014, Bor, Serbia, University of Belgrade, Technical Faculty in Bor, Management Department, Bor, pp. 68-76.

8. Greenberg, H., Weinstein, H., Sweeney, P. (2001). How to hire \& develop your next top performer: The five qualities that make salespeople great, New York, McGraw-Hill.

9. Kurlan, D. (2009). The modern science of salesperson selection. Westborough, A White Paper, Objective Management Group.

10. Loveland, J. M., Lounsbury, J. W., Park, S. H., Jackson, D. W. (2015), "Are salespeolple born or made? Biology, personality, and the career satisfaction of salespeople", Journal of Business \& Industrial Marketing, Vol. 30 No. 2, pp. 233240.

11. Mardani, A., Jusoh, A., Nor, K. MD., Khalifah, Z., Zakwan, N., Valipour, A. (2015), "Multiple criteria decision-making techniques and their applications - a review of the literature from 2000 to 2014", Economic Research-Ekonomska Istrazivanja, Vol. 28 No. 1, pp. 516-571. 
12. Mayer, D., Greenberg, H. M. (1964), "What makes an good salesman?", Harvard Business Review, No. 64411, pp. 119-125.

13. Miller, G. A. (1956), "The magical number seven, plus or minus two: Some limits on our capacity for processing information", The Psychological Review, Vol. 63 No. 2, pp. 81-97.

14. Republic of Macedonia State Statistical Office (2013), National Classification of Activities-NKD Rev. 2, available at: http://www.stat.gov.mk/KlasifikaciiNomenklaturi/NKDRev2.zip (30 April 2016).

15. Saaty, T. L. (1977), "A scaling method for priorities in hierarchical structures", Journal of Mathematical Psychology, Vol. 15 No. 3, pp. 234-281.

16. Saaty, T. L. (1980). Multicriteria decision making: The analytic hierarchy process, Pittsburgh, RWS Publications.

17. Saaty, T. L. (1990), "How to make a decision: The analytic hierarchy process", European Journal of Operational Research, Vol. 48 No. 1, pp. 9-26.

18. Saaty, T. L. (2005). Theory and applications of the analytic hierarchy process: Decision making with benefits, opportunities, costs, and risks, Pittsburgh, RWS Publications.

19. Saaty, T. L., Vargas, L. G. (1991). The logic of priorities, Vol. IIII, Pittsburgh, RWS Publications.

20. Saaty, T. L., Vargas, L. G. (1994). Decision making in economic, political, social, and technological environments with the AHP, Vol. VII, Pittsburgh, RWS Publications.

21. Saaty, T. L., Vargas, L. G. (2012), "Models, methods, concepts and applications of the analytic hierarchy process", New York, Springer Science + Business Media.

22. Saaty, T. L. (2006). Creative thinking, problem solving \& decision making, Pittsburgh, RWS Publications.

23. Yakasai, A. M., Jan, M. T. (2015), "The impact of big five personality traits on salespeople's performance: Exploring the moderating role of culture", Kuwait Chapter of Arabian Journal of Business and Management Review, Vol. 4 No. 5 , pp. 11-26. 


\section{Appendix 1: Questionnaire}

Dear

This survey is done with the aim of demonstrating via research to our present undergraduate students of the SS. Cyril and Methodius University in Skopje, Faculty of Economics-Skopje in Macedonia what sales means, and what they have to be prepared to do if they would like to become a part of it. Thus, we intend to help the companies improve their performance in sales, and in the future to employ salespeople who will be better prepared for the challenges that this profession entails. Since they are very knowledgeable about sales and can easily detect the advantages and disadvantages of this profession, the target group of this survey is sales managers. Your questionnaire answers will not be used separately, but as part of the statistics sample. We ask you to be honest when answering the following questions. Thank you in advance for your cooperation!

1. In what industry does the institution you represent belong to?

2. Position/function that you have:

3. Gender:

4. Age:

a) Male

b) Female

5. Level of education:

a) Vocational education

b) Higher education

c) $M A$

d) PhD

e) Don't want to state

6. Your highest level of education is acquired in:

a) Macedonia

b) Abroad (state where):

7. Number of employees in the institution:

8. Number of employees in the sales sector:

9. Does the institution sell products and/or services, and of what type?

10. What market/s does the institution approach:

11. Does the institution have a higher number of sales in the duration of a month or it makes several sales a year with a higher value?

12. How does the institution sell its products/services? (you can circle more than one answer)
a) Telephone
b) Internet
c) Face-to-face
d) Outsourcing
e) Other (state): 
13. How do you sell the products/services?
a) The buyers visit the institution
b) You visit your buyers
c) Both

14. Does your institution have trainings for its employees?
a) Yes
b) No

If the answer to question 14 is positive, please answer question 15. If it is negative, proceed to question 16.

15. How are the sales trainings for the employees held? (you can circle more than one answer)

a) By more experienced employees in the institution

b) By trainers from outside the institution

c) The employees attend trainings in Macedonia

d) The employees attend trainings abroad

16. Do you attend trainings for the advancement of your knowledge and skills in sales in the duration of a calendar year?
a) Yes
b) No

If the answer to question 16 is positive, please answer questions 17 and 18 , and then proceed to the following questions. If it is negative, proceed to question 19.

17. How often in the duration of a calendar year do you attend trainings for advancement of your skills in sales?
a) Once a year
b) Twice a year
c) Four times a year
d) More than four times a year (state how many times):

18. The trainings that you attend are held in:
a) Macedonia
b) Abroad (state where):

19. How many years of experience do you have in sales:
a) $1-5$
b) $6-10$
c) $11-16$
d) $16+$

20. How have you done sales in your career? (you can circle more than one answer)
a) Face-to-face
b) Group presentations
c) Via internet
d) Via telephone
e) Other (state):

21. What is the best way to do sales, according to you?

22. Since they are best acquainted with the market feedback, how often are the best salespeople included in the system of suggesting and bringing future decisions in the institution, from a tactical and/or strategic aspect?
a) Never
b) Rarely
c) Frequently
d) Almost always 
23. How do you motivate the salespeople?
a) Through rewards
b) Through punishments (explain):

24. How are the salespeople in your institution paid?
a) Fixed salary
b) Sales commission
c) Fixed salary plus commission
d) They are given the chance to choose the model of payment

25. According to you, what is the best way to pay salespeople?

26. How are the sales managers in your institution paid?
a) Fixed salary
b) Personal and managerial sales commission
c) Fixed salary plus personal and managerial commission
d) They are given the chance to choose the model of payment

27. According to you, what is the best way to pay sales managers?

28. Regarding the managers from other sectors, how higher are the benefits for the sales manager, expressed in a higher salary or additional benefits?
a) They have fewer benefits
b) They are equal to the managers from other sectors
c) They have more benefits

29. What kinds of additional benefits do the sales managers have after achieving or exceeding what was expected from them? (you can circle more than one answer)
a) Trips abroad
b) Physical rewards
c) Training for the most successful managers
d) Days off work
e) They don't have additional benefits
f) Other (state them):

30. What kinds of additional benefits do the salespeople have after achieving or exceeding what was expected from them? (you can circle more than one answer
a) Trips abroad
b) Physical rewards
c) Training for the most successful salespeople
d) Days off work
e) They don't have additional benefits
f) Other (state them):

31. The advancement of the sales managers in their career is based on:
a) Their experience
b) Their success in sales

32. The advancement of the salespeople in their career is based on:
a) Their experience
b) Their success in sales

33. According to you, how much time is needed for the new salespeople to learn sales:
a) Less than a year
b) 1-2 years
c) 2-3 years
d) $3+$ years 
34. According to you, how much time is needed for the new salespeople to become experts in sales, who can also train future salespeople:
a) 3 years
b) 3-5 years
c) 5-10 years
d) $10+$ years

35. According to you, what are the three biggest advantages and disadvantages that building a career in sales can bring about?

36. In order for those students who would like to build their career in the field of sales, to prepare for their first employment as salespeople, we ask you to grade the given criteria in the following table according to the importance that you give them when choosing a candidate for this position. You can give the same grade for different criteria. In addition, if there is any criterion that according to you is important but is not stated in the table, we ask you to add and grade it.

\begin{tabular}{|l|l|}
\hline Criteria & Grade of importance (1-5) \\
\hline Formal education & \\
\hline Attended training in the required field of expertise & \\
\hline Attended training out of the required field of expertise & \\
\hline Previous working experience related to sales & \\
\hline Motivation of candidate & \\
\hline English proficiency & \\
\hline Knowledge of a foreign language other than English & \\
\hline Organizational skills & \\
\hline Communication skills & \\
\hline Negotiation skills & \\
\hline Computer skills & \\
\hline Time management & \\
\hline Leadership & \\
\hline Teamwork & \\
\hline Integrity & \\
\hline Problem management & \\
\hline Vision for oneself & \\
\hline Change management & \\
\hline Self-discipline & \\
\hline Looks & \\
\hline Coming from an entrepreneurial family & \\
\hline Coming from a family that was involved in sales & \\
\hline Additional criteria & \\
\hline & \\
\hline
\end{tabular}

Thank you for your time in filling in this questionnaire. 


\section{Appendix 2: Matrixes of pairwise comparisons}

\section{Table 7}

Matrix of pairwise comparisons of the intensities with respect to the criterion 2, priorities and idealized priorities

\begin{tabular}{cccccccc}
\hline Criterion 2 & Excellent & Average & $\begin{array}{c}\text { Below } \\
\text { average }\end{array}$ & Weak & Unsatisfactory & $\begin{array}{c}\text { Priorities } \\
\begin{array}{c}\text { Idealized } \\
\text { Priorities }\end{array}\end{array}$ \\
\hline Excellent & 1 & 3 & 5 & 7 & 9 & 0.5028 & 1.0000 \\
Average & $1 / 3$ & 1 & 3 & 5 & 7 & 0.2602 & 0.5175 \\
Below & $1 / 5$ & $1 / 3$ & 1 & 3 & 5 & 0.1344 & 0.2672 \\
average & & & & & & & \\
Weak & $1 / 7$ & $1 / 5$ & $1 / 3$ & 1 & 3 & 0.0678 & 0.1348 \\
Unsatisfactory & $1 / 9$ & $1 / 7$ & $1 / 5$ & $1 / 3$ & 1 & 0.0348 & 0.0693 \\
\hline
\end{tabular}

C.I. $=0.0607$ C.R. $=0.0546$

Table 8

Matrix of pairwise comparisons of the intensities with respect to the criterion 3 , priorities and idealized priorities

\begin{tabular}{ccccc}
\hline Criterion 3 & $\begin{array}{c}\text { A high } \\
\text { degree }\end{array}$ & $\begin{array}{c}\text { A low } \\
\text { degree }\end{array}$ & Priorities & $\begin{array}{c}\text { Idealized } \\
\text { Priorities }\end{array}$ \\
\hline $\begin{array}{c}\text { A high } \\
\text { degree }\end{array}$ & 1 & 7 & 0.8750 & 1.0000 \\
A low degree & $1 / 7$ & 1 & 0.1250 & 0.1429 \\
\hline C.I. $=$ O C.R. $=0$ & & & &
\end{tabular}

Table 9

Matrix of pairwise comparisons of the intensities with respect to the criterion 4, priorities and idealized priorities

\begin{tabular}{ccccc}
\hline Criterion 4 & $\begin{array}{c}\text { A high } \\
\text { level }\end{array}$ & $\begin{array}{c}\text { A low } \\
\text { level }\end{array}$ & Priorities & $\begin{array}{c}\text { Idealized } \\
\text { Priorities }\end{array}$ \\
\hline A high level & 1 & 7 & 0.8750 & 1.0000 \\
A low level & $1 / 7$ & 1 & 0.1250 & 0.1429 \\
\hline
\end{tabular}

C.I. $=0$ C.R. $=0$

Table 10

Matrix of pairwise comparisons of the intensities with respect to the criterion 5, priorities and idealized priorities

\begin{tabular}{cccccccc}
\hline Criterion 5 & Excellent & $\begin{array}{c}\text { Very } \\
\text { good }\end{array}$ & Good & Weak & Unsatisfactory & $\begin{array}{c}\text { Priorities } \\
\begin{array}{c}\text { Idealized } \\
\text { Priorities }\end{array}\end{array}$ \\
\hline Excellent & 1 & 2 & 3 & 5 & 7 & 0.4436 & 1.0000 \\
Very good & $1 / 2$ & 1 & 2 & 3 & 5 & 0.2618 & 0.5902 \\
Good & $1 / 3$ & $1 / 2$ & 1 & 2 & 3 & 0.1528 & 0.3445 \\
Weak & $1 / 5$ & $1 / 3$ & $1 / 2$ & 1 & 2 & 0.0892 & 0.2010 \\
Unsatisfactory & $1 / 7$ & $1 / 5$ & $1 / 3$ & $1 / 2$ & 1 & 0.0526 & 0.1186 \\
\hline
\end{tabular}

C.I. $=0.0070$ C.R. $=0.0063$ 
Table 11

Matrix of pairwise comparisons of the intensities with respect to the criterion 7 , priorities and idealized priorities

\begin{tabular}{ccccc}
\hline Criterion 7 & A high level & A low level & Priorities & Idealized Priorities \\
\hline A high level & 1 & 7 & 0.8750 & 1.0000 \\
A low level & $1 / 7$ & 1 & 0.1250 & 0.1429 \\
\hline
\end{tabular}

C.I. $=0$ C.R. $=0$

Table 12

Matrix of pairwise comparisons of the intensities with respect to the criterion 8, priorities and idealized priorities

\begin{tabular}{cccccccc}
\hline Criterion 8 & Excellent & $\begin{array}{c}\text { Very } \\
\text { good }\end{array}$ & Good & Weak & Unsatisfactory & $\begin{array}{c}\text { Priorities } \\
\text { Idealized } \\
\text { Priorities }\end{array}$ \\
\hline Excellent & 1 & 2 & 3 & 5 & 7 & 0.4436 & 1.0000 \\
Very good & $1 / 2$ & 1 & 2 & 3 & 5 & 0.2618 & 0.5902 \\
Good & $1 / 3$ & $1 / 2$ & 1 & 2 & 3 & 0.1528 & 0.3445 \\
Weak & $1 / 5$ & $1 / 3$ & $1 / 2$ & 1 & 2 & 0.0892 & 0.2010 \\
Unsatisfactory & $1 / 7$ & $1 / 5$ & $1 / 3$ & $1 / 2$ & 1 & 0.0526 & 0.1186 \\
\hline
\end{tabular}

C.I. $=0.0070$ C.R. $=0.0063$

Table 13

Matrix of pairwise comparisons of the intensities with respect to the criterion 9, priorities and idealized priorities

\begin{tabular}{cccccccc}
\hline Criterion 9 & Excellent & $\begin{array}{c}\text { Very } \\
\text { good }\end{array}$ & Good & Weak & Unsatisfactory & $\begin{array}{c}\text { Priorities } \\
\text { Idealized } \\
\text { Priorities }\end{array}$ \\
\hline Excellent & 1 & 2 & 3 & 5 & 7 & 0.4436 & 1.0000 \\
Very good & $1 / 2$ & 1 & 2 & 3 & 5 & 0.2618 & 0.5902 \\
Good & $1 / 3$ & $1 / 2$ & 1 & 2 & 3 & 0.1528 & 0.3445 \\
Weak & $1 / 5$ & $1 / 3$ & $1 / 2$ & 1 & 2 & 0.0892 & 0.2010 \\
Unsatisfactory & $1 / 7$ & $1 / 5$ & $1 / 3$ & $1 / 2$ & 1 & 0.0526 & 0.1186 \\
\hline
\end{tabular}

C.I. $=0.0070$ C.R. $=0.0063$ 


\section{About the authors}

Violeta Cvetkoska holds a PhD in Economics, and is an Assistant Professor of Management Science at the Ss. Cyril and Methodius University in Skopje, Faculty of Economics-Skopje. She has participated in many international conferences, symposia, seminars, trainings and workshops in Macedonia and abroad. She is an author of several scientific papers published in the proceedings of international conferences, symposia and journals. Her research focuses on management science/operations research, business analytics, multiple-criteria decision making and data envelopment analysis. She is a member of the Croatian Operational Research Society (CRORS). Author can be contacted at vcvetkoska@eccf.ukim.edu.mk

Filip Iliev received his MA degree from Ss. Cyril and Methodius University in Skopje, Faculty of Economics-Skopje in 2015. In 2011 he started working as a consultant at WVP Group-Graz - WVP AD Skopje, Insurance Broker Agency. In July 2015 he acquired the position of Insurance Broker, and from August 2015 he has been employed at WVP AD Skopje, Insurance Broker Agency. He has attended over 300 trainings in Macedonia and abroad, on topics that are closely connected to his field of interest: sales, personal development, organizational behaviour, management, business communication, business planning, and behaviourism in management, insurance, finances and investment funds. Author can be contacted at filipwvp@gmail.com 